\title{
IMPLEMENTASI ANALISA KOMPONEN UTAMA UNTUK MEREDUKSI VARIABEL YANG MEMPENGARUHI PERBAIKAN PADA FUNGSI GINJAL TIKUS
}

\author{
Fitrianingsih $^{a}$, Sugiyarto ${ }^{b}$ \\ a Program Studi Matematika FMIPA UAD \\ Jl. Ring Road Selatan, Tamanan, Bantul, Yogyakarta, fitrianingsih072@yahoo.com \\ ${ }^{\mathrm{b}}$ Program Studi Matematika FMIPA UAD \\ Jl. Ring Road Selatan, Tamanan, Bantul, Yogyakarta, sugiyartophd@ gmail.com
}

\begin{abstract}
ABSTRAK
Penelitian ini bertujuan untuk mereduksi variabel yang mempengaruhi fungsi ginjal pada tikus. Untuk memperoleh informasi yang diinginkan, maka diperlukan suatu metode yang tepat agar dapat digunakan dalam mengolah data yang sudah ada. Ada banyak metode yang digunakan untuk mereduksi variabel, di antaranya yaitu Principal Component Analysis (PCA) dan Factor Analysis (FA). Metode yang akan digunakan dalam penelitian ini adalah metode principal component analysis (PCA) atau analisa komponen utama. PCA merupakan salah satu metode dalam analisis multivariat yang secara khusus dikembangkan untuk mereduksi dimensi data yang ukurannya besar menjadi lebih sederhana tanpa harus kehilangan informasi data asli. Pada penelitian ini, metode PCA digunakan untuk mereduksi jumlah variabel, sehingga dari 8 variabel yang ada hanya akan diketahui 3 variabel yang benar-benar mempengaruhi perbaikan fungsi ginjal tikus, dimana 3 variabel yang dihasilkan tersebut dapat mewakili 8 variabel yang ada pada dataset. Variabel baru hasil reduksi akan dijadikan sebagai variabel input untuk membuat model persamaan regresinya untuk melihat sebagaimana pengaruh variabel tersebut terhadap perbaikan fungsi ginjal tikus. Adapun model regresi akhir hasil komponen utama yaitu

$$
Y=\beta_{0}+\beta_{1} P C_{1}+\beta_{2} P C_{2}+\beta_{3} P C_{3}
$$
\end{abstract}

Kata Kunci : matriks kovarian, nilai eigen, vektor eigen, PCA, regresi berganda.

\begin{abstract}
This study aims to reduce the variable that affect recovery of mice kidney function. In order to obtain the desired information required an appropriate method to be used in processing existing data. There are many methods used to reduce variables, including Principal Component Analysis (PCA) and Factor Analysis (FA). The method to be used in this research is principal component analysis method (PCA). PCA is one of the methods in multivariate analysis that is specifically developed to reduce the dimensions of large-size data becomes simpler without losing the original data information. In this study, PCA method is used to reduce the number of variables, so that from 8 variables that will only be known 3 variables that really affect the kidney function, where the 3 variables produced can represent 8 variables that exist in the dataset. The new variable of the reduction result will be used to make the model of regression equation to see the effect of these variables on recovery kidney function. As for the final regression model of principal component that is
\end{abstract}

$$
Y=\beta_{0}+\beta_{1} P C_{1}+\beta_{2} P C_{2}+\beta_{3} P C_{3}
$$

Keywords: covariance matrix, eigenvalue, eigenvector, PCA, multiple regression. 


\section{Pendahuluan}

Masalah pengurangan variabel dari suatu data multivariat yang besar sering menjadi topik yang menarik untuk dibahas. Beberapa masalah yang timbul dalam mereduksi variabel tersebut adalah bagaimana caranya mendapatkan jumlah variabel yang lebih kecil namun tetap mampu mempertahankan sebagian besar informasi yang terkandung pada data asal (Mattjik \& Sumertajaya, 2011). Pada analisis multivariat, terdapat dua prosedur atau metode statistik yang digunakan dalam mereduksi dimensi/variabel pada suatu data, yaitu Principal Component Analysis (PCA) dan Factor Analysis (FA). Prosedur ini dirancang untuk mengurangi dimensi ruang data untuk menemukan, memvisualisasikan, dan menginterpretasikan ketergantungan di antara kumpulan variabel, atau untuk membantu menstabilkan pengukuran untuk analisis statistik tambahan seperti analisis regresi atau analisis cluster (Neil, 2002).

Ginjal memiliki peranan yang sangat vital sebagai organ tubuh manusia terutama dalam sistem urinaria. Pada manusia, ginjal berfungsi untuk mengatur keseimbangan cairan dalam tubuh, mengatur konsentrasi garam dalam darah dan keseimbangan asam-basa darah, serta sekresi bahan buangan dan kelebihan garam (Pearce, 1999). Fungsi ginjal bagi tubuh manusia sangat vital. Oleh karena itu, jika ginjal mengalami kerusakan maka akan menimbulkan masalah atau komplikasi penyakit yang lain. Salah satu yang perlu dihindari adalah penyakit gagal ginjal yang merupakan salah satu penyakit yang sangat berbahaya. Pada penelitian ini, dilakukan studi kasus pengaruh perlakuan pemberian ekstrak tanaman obat (independent variable) terhadap fungsi ginjal tikus (dependent variable). Dalam kasus ini, metode Principal Component Analysis (PCA) atau analisa komponen utama akan digunakan sebagai metode untuk mereduksi variabel-variabel perlakuannya (independent variable).

Analisa komponen utama adalah salah satu fitur ekstraksi (reduksi) variabel yang banyak digunakan. Bisa dikatakan analisa komponen utama merupakan analisa tertua dan paling terkenal dari teknik statistika multivariat (Jollife, 2002). Metode analisa komponen utama diperkenalkan oleh Karl Pearson pada tahun 1901 dan selanjutnya dikembangkan oleh Harold Hotelling pada tahun 1933 dan bertujuan untuk menyederhanakan variabel yang diamati dengan cara menyusutkan dimensinya (Chatfield \& Collins, 2000). 
Analisa komponen utama merupakan salah satu analisis multivariat yang digunakan untuk mereduksi dimensi data dari yang berukuran besar dan saling berkorelasi menjadi dimensi yang lebih kecil dan tidak saling berkorelasi. Namun, walaupun dimensi data menjadi lebih kecil, kita tidak akan kehilangan banyak informasi karena variasi data tetap dipertahankan minimal 70-80\% (Johnson \& Wichern, 1992). Pada beberapa penelitian terdahulu, analisa komponen banyak digunakan sebagai metode dalam mereduksi variabel, di antaranya digunakan dalam bidang ekonomi untuk mengatasi multikolinearitas dalam menentukan investasi (Soemartini, 2007), bidang kesehatan digunakan untuk mereduksi faktor-faktor yang mempengaruhi penyakit jantung koroner (Hendro M., dkk: 2012) dan bidang pendidikan digunakan dalam penentuan faktor dominan yang mempengaruhi prestasi belajar siswa (Hardika, dkk, 2013).

Metode analisa komponen utama telah banyak digunakan pada penelitianpenelitian sebelumnya untuk mereduksi dimensi/variabel dalam mengatasi permasalahan di berbagai bidang. Oleh karena itu, dalam penelitian ini metode analisa komponen utama akan digunakan untuk mereduksi dimensi/variabel di bidang Farmakokinetika pada studi kasus perbaikan fungsi ginjal tikus yang kemudian dibuat model persamaan regresinya.

\section{Metode Penelitian}

Pada penelitian ini, metode yang digunakan yaitu metode analisa komponen utama. Metode ini digunakan untuk mereduksi variabel sehingga dari 8 variabel yang ada pada dataset akan diperoleh 3 variabel baru yang mewakili 8 variabel asal tersebut. Ketiga variabel hasil reduksi tersebut merupakan faktor-faktor yang mempengaruhi fungsi ginjal pada tikus.

Data yang akan digunakan berupa data primer yang terdiri dari 80 sampel tikus yang diberikan dosis ekstrak tanaman obat untuk mengetahui pengaruhnya terhadap perbaikan fungsi ginjal tikus yang dilihat melalui besarnya kadar BUN. Variabel-variabel yang akan diteliti terdiri dari 1 variabel terikat (dependent) dan 8 variabel bebas (independent). Tahapan pertama yang dilakukan pada penelitian ini adalah membentuk matriks kovarian dari 8 variabel, kedua menghitung nilai dan vektor eigen dari matriks tersebut, kemudian terakhir membentuk komponen utama dari 8 variabel berdasarkan nilai dan 
vektor eigen yang diperoleh. Setelah diperoleh hasil komponen utamanya, maka akan dibentuk model persamaan regresi akhir untuk melihat pengaruhnya terhadap perbaikan fungsi ginjal tikus. Adapun variabel-variabel dalam penelitian ini dapat dilihat pada Tabel 1 berikut ini.

Tabel 1. Variabel Penelitian

\begin{tabular}{cl}
\hline Variabel & \multicolumn{1}{c}{ Keterangan } \\
\hline $\mathrm{Y}$ & $\begin{array}{l}\text { Kadar BUN } \\
\text { Dosis pemberian serbuk ekstrak } \\
\text { seledri }\end{array}$ \\
$\mathrm{X}_{1}$ & $\begin{array}{l}\text { Dosis pemberian serbuk ekstrak } \\
\text { meniran }\end{array}$ \\
$\mathrm{X}_{2}$ & $\begin{array}{l}\text { Dosis pemberian serbuk ekstrak } \\
\text { pegagan }\end{array}$ \\
$\mathrm{X}_{3}$ & $\begin{array}{l}\text { Dosis pemberian serbuk ekstrak kunir } \\
\text { Dosis pemberian kombinasi serbuk } \\
\mathrm{X}_{4}\end{array}$ \\
$\mathrm{X}_{5}$ & $\begin{array}{l}\text { ekstrak meniran-seledri } \\
\text { Dosis pemberian kombinasi serbuk } \\
\text { ekstrak meniran-kunir }\end{array}$ \\
$\mathrm{X}_{6}$ & $\begin{array}{l}\text { Dosis pemberian kombinasi serbuk } \\
\text { ekstrak meniran-pegagan }\end{array}$ \\
$\mathrm{X}_{7}$ & $\begin{array}{l}\text { Dosis pemberian kombinasi serbuk } \\
\text { ekstrak pegagan-kunir }\end{array}$ \\
$\mathrm{X}_{8}$
\end{tabular}

Perhitungan dengan menggunakan metode analisa komponen utama didasarkan pada perhitungan nilai eigen dan vektor eigen dari matriks kovarian yang menyatakan penyebaran data dari suatu dataset. Adapun langkah-langkah perhitungan analisa komponen utama secara umum sebagai berikut:

1. Menghitung matriks kovarian dengan persamaan berikut:

$$
s_{m n}=\operatorname{Cov}\left(X_{m}, X_{n}\right)=\frac{1}{k-1} \sum_{j=1}^{k}\left(x_{j m}-\bar{x}_{m}\right)\left(x_{j n}-\bar{x}_{n}\right)
$$

dimana $m, n=1,2, \ldots, p$.

Sehingga diperoleh matriks kovarian sampel

$$
S=\left[\begin{array}{cccc}
s_{11} & s_{12} & \ldots & s_{1 p} \\
s_{21} & s_{22} & \ldots & s_{2 p} \\
\vdots & \vdots & \ddots & \vdots \\
s_{p 1} & s_{p 2} & \ldots & s_{p p}
\end{array}\right]
$$

2. Menghitung nilai eigen dan vektor eigen dengan menyelesaikan persamaan berikut:

$$
\begin{aligned}
& (A-\lambda I)=0 \\
& (A-\lambda I) X=0
\end{aligned}
$$

3. Menentukan variabel baru (principal component) dengan mengalikan variabel asli dengan matriks vektor eigen.

Sedangkan variansi yang dapat dijelaskan oleh variabel baru tergantung kontribusi $\rho_{\mathrm{i}}$, dari masing-masing nilai eigen yang dihitung dengan persamaan berikut:

$$
\rho_{i}=\frac{\lambda_{i}}{\sum_{j=1}^{p} \lambda_{j}} \times 100 \%
$$

Principal Component Analysis (PCA)

Definisi 1. Misalkan diketahui vektor acak $\mathrm{p}$ yaitu $\mathrm{X}_{1}, \mathrm{X}_{2}, \ldots, \mathrm{X}_{\mathrm{p}}$. Komponen utama dari variabel $\mathrm{X}_{1}, \mathrm{X}_{2}, \ldots, \mathrm{X}_{\mathrm{p}}$ adalah vektor dari $\mathrm{PC}_{1}, \mathrm{PC}_{2}, \ldots, \mathrm{PC}_{\mathrm{k}}$ yang diperoleh dengan syarat bahwa:

1. $\mathrm{k}<\mathrm{p}$ 
2. $\operatorname{Var}\left(\mathrm{PC}_{1}\right)>\operatorname{Var}\left(\mathrm{PC}_{2}\right)>\ldots>\operatorname{Var}\left(\mathrm{PC}_{\mathrm{k}}\right)$

3. $\operatorname{Cov}\left(\mathrm{PC}_{\mathrm{i}}, \mathrm{PC}_{\mathrm{j}}\right)=0$, dimana $\mathrm{i} \neq \mathrm{j}$.

Menurut Gasperz

menyatakan bahwa komponen utama (principal component) didefinisikan sebagai kombinasi linier dari $\mathrm{p}$ variabel asal yang dinyatakan dalam bentuk persamaan matriks berikut:

$$
P C_{p \times 1}=A_{p \times p} X_{p \times 1}
$$

dimana A merupakan matriks konstanta, C dan $\mathrm{X}$ adalah matriks variabel baru dan matriks variabel asal. Persamaan di atas dinyatakan sebagai berikut:

$$
\left[\begin{array}{c}
P C_{1} \\
P C_{2} \\
\vdots \\
P C_{p}
\end{array}\right]=\left[\begin{array}{cccc}
a_{11} & a_{12} & \cdots & a_{1 p} \\
a_{21} & a_{22} & \cdots & a_{2 p} \\
\vdots & \vdots & \ddots & \vdots \\
a_{p 1} & a_{p 2} & \cdots & a_{p p}
\end{array}\right]\left[\begin{array}{c}
X_{1} \\
X_{2} \\
\vdots \\
X_{p}
\end{array}\right]
$$

Setelah memperoleh matriks kovarian, nilai eigen dan vektor eigen, maka persamaan komponen utama dapat dibentuk, yaitu:

$P C_{1}=a_{11} X_{1}+a_{21} X_{2}+\cdots+a_{p 1} X_{p}=a_{p 1}^{t} X$

$P C_{2}=a_{12} X_{1}+a_{22} X_{2}+\cdots+a_{p 2} X_{p}=a_{p 2}^{t} X$

$\vdots$

$P C_{p}=a_{1 p} X_{1}+a_{2 p} X_{2}+\cdots+a_{p p} X_{p}=a_{p p}^{t} X$

Ada dua cara yang digunakan untuk menentukan jumlah komponen utama. Pertama, dengan melihat total varian yang AdMathEdu | Vol.8 No.2| Desember 2018 kedua adalah dengan melihat nilai eigen terbesar. Pada penelitian ini untuk menentukan jumlah komponen utama yang dihasilkan pada analisa komponen utama adalah dengan melihat 3 nilai eigen terbesar dan besarnya total varian.

Model Regresi Linier Berganda

Analisis regresi linier berganda adalah hubungan secara linear antara dua atau lebih variabel independen $\left(X_{1}, X_{2}, \ldots, X_{p}\right)$ dengan variabel dependen $(Y)$. Bentuk umum model regresi linier berganda dengan $\mathrm{p}$ variabel bebas adalah seperti pada persamaan berikut (Kutner, Nachsteim \& Neter, 2004).

$Y_{i}=\beta_{0}+\beta_{1} X_{i 1}+\beta_{2} X_{i 2}+\cdots+\beta_{p} X_{i p}+\varepsilon_{i}$ dengan:

$Y_{i}$ adalah variabel tidak bebas untuk pengamatan ke-i, untuk $i=1,2, \ldots, n$.

$\beta_{0}$ adalah parameter.

$\beta_{1}, \beta_{3}, \ldots, \beta_{n}$ adalah koefisien.

$X_{i 1}, X_{i 2}, \ldots, X_{i p}$ adalah variabel bebas.

$\varepsilon_{\text {i }}$ adalah sisa (error).

\section{Hasil dan Pembahasan}

Analisa dengan menggunakan metode analisa komponen utama dilakukan apabila terdapat hubungan/keterkaitan Implementasi... (Fitrianingsih)

komponen utama adalah membuat sejumlah variabel baru yang tidak memiliki 
hubungan antarvariabelnya (kovarian $=0$ ) dan jumlah variabel yang ada lebih sedikit dari jumlah variabel awal. Pada penelitian ini, implementasi dari analisa komponen utama menggunakan MATLAB.

Langkah awal analisa komponen utama adalah menghitung nilai kovarian antarvariabel, karena pada dasarnya analisa komponen utama dapat dilakukan jika variabel yang diteliti memiliki hubungan/keterkaitan. Pada analisa ini dilakukan perhitungan nilai kovarian yang kemudian dibentuk dalam sebuah matriks kovarian. Dari matriks kovarian nantinya akan dilakukan analisa komponen utama dengan melihat nilai eigen dari masingmasing variabel. Variabel baru (principal component) yang terbentuk didasarkan pada 3 nilai eigen terbesar dengan total varian yang lebih besar dari 70\%. Suatu nilai eigen menunjukkan besarnya sumbangan dari komponen terhadap variansi seluruh variabel asli.

Tabel 2. Nilai Eigen Hasil Analisa Komponen Utama

\begin{tabular}{cccc}
\hline \multirow{2}{*}{ Komponen } & \multicolumn{3}{c}{ Inisial Nilai Eigen } \\
& $\begin{array}{c}\text { Nilai } \\
\text { Eigen }\end{array}$ & $\begin{array}{c}\text { Varian } \\
\%\end{array}$ & $\begin{array}{c}\text { Kumulatif } \\
\%\end{array}$ \\
\hline 1 & 0,1296 & $39,27 \%$ & $39,27 \%$ \\
2 & 0,0675 & $20,45 \%$ & $59,72 \%$ \\
3 & 0,0521 & $15,79 \%$ & $75,51 \%$ \\
4 & 0,0506 & $15,33 \%$ & $90,84 \%$ \\
5 & 0,0255 & $7,73 \%$ & $98,57 \%$ \\
6 & 0,0032 & $0,97 \%$ & $99,54 \%$ \\
7 & 0,0014 & $0,44 \%$ & $99,98 \%$ \\
8 & 0,0001 & $0,02 \%$ & $100 \%$ \\
\hline
\end{tabular}

Implementasi... (Fitrianingsih)
Tabel 2 menjelaskan nilai eigen dari masing-masing variabel beserta variannya. Pada tabel tersebut diperoleh 3 variabel baru yang memiliki nilai eigen terbesar yaitu masing-masing dengan nilai 0,1296; 0,0675 dan 0,0521. Komponen pertama dengan nilai eigen 0,1296 memiliki variansi sebesar 39,27\%. Komponen kedua dengan nilai eigen 0,0675 memiliki variansi sebesar 20,45\%. Komponen ketiga dengan nilai eigen 0,0521 memiliki variansi sebesar $15,79 \%$. Ketiga variabel baru ini mampu menjelaskan variansi data sebesar $75,51 \%$ yang dilihat dari nilai kumulatifnya. Adapun grafik nilai eigen ditunjukkan pada gambar berikut ini.

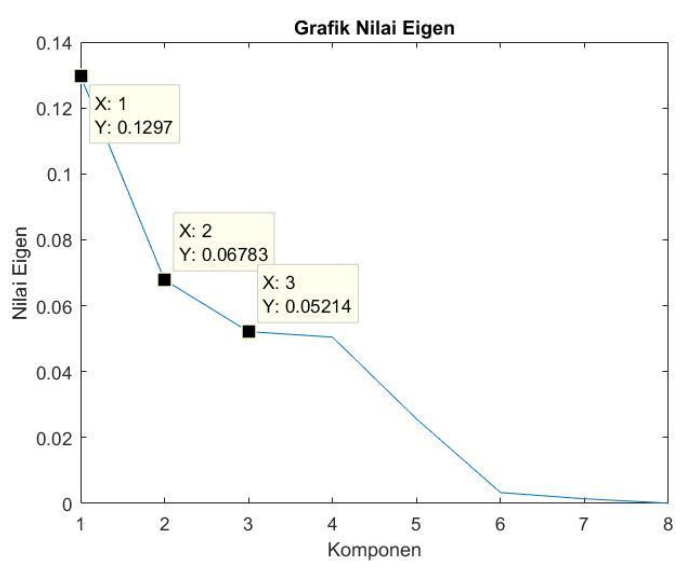

Gambar 1. Grafik Nilai Eigen

Gambar 1 menunjukkan grafik nilai eigen secara terurut. Berdasarkan kriteria nilai eigen dalam penentuan jumlah komponen utama, dari grafik tersebut diperoleh 3 nilai eigen terbesar yaitu 
$\lambda_{1}>\lambda_{2}>\lambda_{3}>0$. Seperti yang telah dijelaskan sebelumnya, maka dapat diketahui bahwa jumlah komponen utama yang terbentuk sebanyak 3 komponen.

Pemilihan komponen utama dapat pula dilakukan dengan melihat Proporsi Kumulatif Varian (PKV) yang dipilih mampu menerangkan total varian data sekitar 70-80\%. PKV digunakan untuk mewakili data dengan mempertahankan informasi sebanyak varian PC tersebut. PKV dapat dihitung dengan varian-varian yang tersusun pada matriks eigenvalue atau menjumlahkan proporsi varian dari setiap komponen utama. Berdasarkan Tabel 2 diperoleh nilai PKV dari 3 komponen yang terbentuk sebesar $75,51 \%$ dimana nilainya lebh besar dari $70 \%$, sehingga dapat diketahui pula bahwa jumlah komponen utama yang terbentuk sebanyak 3 komponen.

Langkah selanjutnya yaitu mencari vektor eigen dari nilai eigen yang diperoleh sebelumnya. Berdasarkan vektor eigen yang diperoleh tersebut, akan diketahui variabel apa saja yang termasuk dalam ketiga komponen utama yang dihasilkan, dan variabel manakah yang benar-benar mempengaruhi perbaikan pada fungsi ginjal tikus. Elemen-elemen yang terdapat pada matriks vektor eigen merupakan nilai loading/koefisien pada komponen utama yang terbentuk.

Loading/koefisien menyatakan besarnya variansi suatu variabel yang mampu dijelaskan oleh suatu komponen utama. Variansi yang besar berarti bahwa variabel mempunyai hubungan/pengaruh yang besar terhadap komponen utama yang mewakili data variabel-variabel yang mempengaruhi perbaikan pada fungsi ginjal tikus. Adapun tabel Loading/koefisien dari ketiga komponen utama yang ditunjukkan pada Tabel 3 berikut.

Tabel 3. Loading/Koefisien Principal Component

\begin{tabular}{cccc}
\hline \multirow{2}{*}{ Variabel } & \multicolumn{3}{c}{ Komponen } \\
& 1 & 2 & 3 \\
\hline 1 & $\mathbf{0 , 4 2 2 6}$ & $-0,1849$ & $-0,4127$ \\
2 & $\mathbf{- 0 , 3 3 6 2}$ & 0,1073 & 0,0121 \\
3 & $\mathbf{0 , 5 5 8 7}$ & 0,2807 & $-0,0192$ \\
4 & $\mathbf{- 0 , 4 9 1 1}$ & 0,3541 & $-0,4048$ \\
5 & $\mathbf{0 , 3 1 4 9}$ & 0,2953 & 0,0194 \\
6 & $-0,0311$ & $\mathbf{0 , 7 6 6 4}$ & 0,0323 \\
7 & $-0,2342$ & $\mathbf{- 0 , 2 6 4 5}$ & 0,0730 \\
8 & 0,0029 & 0,0739 & $\mathbf{0 , 8 1 1 5}$ \\
\hline
\end{tabular}

Tabel 3 menjelaskan hubungan antar variabel asli dengan variabel baru (principal component) yang dibentuk dengan analisa komponen utama.

Nilai loading/koefisien yang dipilih yaitu nilai terbesar di antara ketiga component yang dianggap mampu menjelaskan variabel yang mempengaruhi perbaikan fungsi ginjal pada tikus (dicetak 
tebal). Sedangkan untuk variabel lain yang memiliki nilai loading/keofisien yang lebih kecil dianggap kurang berpengaruh terhadap pembentukan komponen utama, dan dengan menggunakan 3 variabel baru yang terbentuk telah mewakili 8 variabel pada data asli. Selanjutnya akan dijelaskan lebih rinci hasil dari komponen utama sebagai variabel baru yang terbentuk beserta besar variannya pada Tabel 4 berikut.

Tabel 4. Ringkasan Analisa Komponen Utama (PCA)

\begin{tabular}{cccc}
\hline $\begin{array}{c}\text { Principal } \\
\begin{array}{c}\text { Component } \\
\text { (PC) }\end{array}\end{array}$ & Variabel & $\begin{array}{c}\text { Faktor } \\
\text { Loading }\end{array}$ & Varian \\
\hline & $\mathrm{X}_{1}$ & 0,4226 & \\
& $\mathrm{X}_{2}$ & $-0,3362$ & \\
$\mathrm{PC}_{1}$ & $\mathrm{X}_{3}$ & 0,5587 & $39,27 \%$ \\
& $\mathrm{X}_{4}$ & $-0,4911$ & \\
& $\mathrm{X}_{5}$ & 0,3149 & \\
$\mathrm{PC}_{2}$ & $\mathrm{X}_{6}$ & 0,7664 & $20,04 \%$ \\
$\mathrm{PC}_{3}$ & $\mathrm{X}_{7}$ & $-0,2645$ & \\
\hline
\end{tabular}

Berdasarkan perhitungan pada

Tabel 3, diperoleh hasil akhir berupa nilai dari variabel baru yang merupakan komponen utamanya. Hasil komponen utama merupakan hasil kombinasi linear data asal yang telah distandarisasi dengan transpose dari vektor eigennya, yaitu sebagai berikut:

$$
\begin{aligned}
\mathrm{PC}_{1}= & 0,4226 \mathrm{X}_{1}-0,3362 \mathrm{X}_{2}+0,5587 \mathrm{X}_{3}- \\
& 0,4911 \mathrm{X}_{4}+0,3149 \mathrm{X}_{5}-0,0311 \mathrm{X}_{6}- \\
& 0,2342 \mathrm{X}_{7}+0,0029 \mathrm{X}_{8}
\end{aligned}
$$

$$
\begin{aligned}
P_{2}= & -0,1849 X_{1}+0,1073 X_{2}+0,2807 X_{3}+ \\
& 0,3541 X_{4}+0,2953 X_{5}+0,76644 X_{6} \\
& -0,2645 X_{7}+0,0739 X_{8}
\end{aligned}
$$

$$
\begin{aligned}
\mathrm{PC}_{2}= & -0,4127 \mathrm{X}_{1}+0,0121 \mathrm{X}_{2}-0,0192 \mathrm{X}_{3}- \\
& 0,4048 \mathrm{X}_{4}+0,0194 \mathrm{X}_{5}+0,0323 \mathrm{X}_{6}+ \\
& 0,0730 \mathrm{X}_{7}+0,8115 \mathrm{X}_{8}
\end{aligned}
$$

Hasil perhitungan di atas dapat dituliskan pada Tabel 5 berikut.

Tabel 5. Hasil Komponen Utama (PC)

\begin{tabular}{ccc}
\hline $\mathrm{PC}_{1}$ & $\mathrm{PC}_{2}$ & $\mathrm{PC}_{3}$ \\
\hline$-0,0486$ & 0,0967 & 0,0813 \\
$-0,2870$ & $-0,1119$ & 0,3816 \\
0,7766 & $-0,0188$ & 0,1763 \\
$-0,6461$ & 0,1373 & $-0,0628$ \\
$-0,0508$ & $-0,4739$ & $-0,2803$ \\
0,0763 & 0,2775 & 0,1159 \\
$-0,0418$ & 0,3426 & $-0,0476$ \\
0,2142 & 0,2062 & $-0,4290$ \\
$-0,0473$ & $-0,2516$ & 0,0067 \\
0,0546 & $-0,2039$ & 0,0578 \\
\hline
\end{tabular}

Berdasarkan perhitungan diatas diperoleh varian dan kovarian dari masingmasing komponen utama, sebagai berikut:

$$
\begin{gathered}
\operatorname{Var}\left(\mathrm{PC}_{1}\right)=0,1296=\lambda_{1} \\
\operatorname{Var}\left(\mathrm{PC}_{2}\right)=0,0675=\lambda_{2} \\
\operatorname{Var}\left(\mathrm{PC}_{3}\right)=0,0521=\lambda_{3} \\
\operatorname{Cov}\left(\mathrm{PC}_{1}, \mathrm{PC}_{2}\right)=0 \\
\operatorname{Cov}\left(\mathrm{PC}_{1}, \mathrm{PC}_{3}\right)=0 \\
\operatorname{Cov}\left(\mathrm{PC}_{2}, \mathrm{PC}_{3}\right)=0
\end{gathered}
$$

Pada perhitungan tersebut diperoleh bahwa besarnya varian masing-masing komponen yang terbentuk setara dengan nilai eigen yang diperoleh, serta nilai kovarian antar komponen utama sebesar 0 dimana hal tersebut menunjukkan bahwa antar komponen utama (PC) bersifat saling 
bebas (tidak ada hubungan). Oleh karena itu, berdasarkan perhitungan di atas diperoleh bahwa pembentukan komponen utama memenuhi kriteria yang ada.

Selanjutnya, berdasarkan 3 komponen yang terbentuk, maka dapat dibuat model regresi sebagai berikut:

$$
Y=\beta_{0}+\beta_{1} P C_{1}+\beta_{2} P C_{2}+\beta_{3} P C_{3}
$$

\section{Kesimpulan}

Berdasarkan hasil dan pembahasan sebelumnya, maka dapat disimpulkan bahwa:

1. Perhitungan PCA menghasilkan 3 variabel baru (principal component) dari 8 variabel yang diteliti, yang merupakan komponen utama yang mempengaruhi perbaikan pada fungsi ginjal tikus

2. Komponen utama yang terbentuk adalah $\mathrm{PC}_{1}, \mathrm{PC}_{2}$ dan $\mathrm{PC}_{3}$. Komponen utama pertama $\left(\mathrm{PC}_{1}\right)$ terdiri dari variabel $\mathrm{X}_{1}$, $\mathrm{X}_{2}, \mathrm{X}_{3}, \mathrm{X}_{4}$ dan $\mathrm{X}_{5}$ dengan total variansi sebesar 39,27\%. Komponen utama kedua $\left(\mathrm{PC}_{2}\right)$ terdiri dari variabel $\mathrm{X}_{6}$ dan $\mathrm{X}_{7}$ dengan total variansi sebesar $20,45 \%$. Komponen utama ketiga $\left(\mathrm{PC}_{3}\right)$ terdiri dari variabel $\mathrm{X}_{5}$ dengan total variansi sebesar $15,79 \%$. Ketiga variabel baru (principal component) yang terbentuk mampu menjelaskan proporsi varian kumulatif sebesar $75,51 \%$ artinya perbaikan fungsi ginjal tikus mampu dijelaskan hanya dengan tiga variabel yang terbentuk

3. Dari hasil reduksi komponen utama diperoleh model persamaan regresi berikut:

$$
Y=\beta_{0}+\beta_{1} P C_{1}+\beta_{2} P C_{2}+\beta_{3} P C_{3}
$$

dengan: $\mathrm{PC}_{1}=\mathrm{X}_{1}, \mathrm{X}_{2}, \mathrm{X}_{3}, \mathrm{X}_{4}, \mathrm{X}_{5}$

$$
\mathrm{PC}_{2}=\mathrm{X}_{6}, \mathrm{X}_{7}
$$$$
\mathrm{PC}_{3}=\mathrm{X}_{8}
$$

\section{Ucapan Terimakasih}

Dalam pembuatan paper ini, Penulis mengucapkan terimakasih kepada bapak Sugiyarto, Ph.D selaku dosen pembimbing yang telah banyak membantu dan mengarahkan dalam pembuatan paper ini. Terimakasih kepada bapak Dr. rer. nat, Endang D., M.Si., Apt., beserta rekanrekan mahasiswa dari Fakultas Farmasi Universitas Ahmad Dahlan yang telah membantu dalam proses pengambilan data pada penelitian ini. Terimakasih pula kepada teman-teman seperjuangan yang selalu memberikan semangat, dukungan serta motivasi dalam penyusunan paper ini.

\section{Pustaka}

Chatfield, C. and Collins, A.J., 2000, Introduction to Multivariate 
Analysis, New York : Chapman and Hall.

Gasperz, Vincent, 1995, Teknik Analysis dalam Penelitian Percobaan, New York : Chapman dan Hall.

Hardika, juliarti., dkk., 2013, "Penerapan Analisis Komponen Utama dalam Penentuan Dominan yang Mempengaruhi Prestasi Belajar Siswa”, Jurnal Pendidikan, Vol. 1, No. 6, pp 507-516.

Hendro M., Galih, dkk, 2012, "Penggunaan Metodologi Analisa Komponen Utama (PCA) untuk Mereduksi Faktor-Faktor yang Mempengaruhi Penyakit Jantung Koroner", Yogyakarta : Jurnal Kesehatan.

Jolliffe, I. T., 2002, Principal Component Analysis (2th ed), New York : Springer-Verlag.

Johnson, R. A. and Wichern, D. W., 1992, Applied Multivariate Statistical Analysis (3th ed), New Jersey : Pearson Prentice-Hall, Inc.

Kutner, M.H., C.J. Nachtsheim., and J. Neter, 2004, Applied Linear Regression Models (4th ed), New York: McGraw-Hill Companies, Inc.

Mattjik, A. A. dan Sumertajaya, I. M., 2011, Sidik Peubah Ganda, Bogor : IPB Press.

Pearce, Evelyn, 1999, Anatomi dan Fisiologi untuk Paramedis, Terjemahan Sri Yuliani Handoyo, Jakarta : Gramedia.

Soemartini, 2008, "Aplikasi Principal Component Analysis (PCA) dalam Mengatasi Multikolinearitas untuk Menentukan Investasi di Indonesia", Bandung : Jurnal Statistik.

Timm, N. H., 2002, Applied Multivariate Analysis, California : Brooks/Cole Publishing. 